\title{
ISLAMIC CULTURAL NOTES IN ELT INSTRUCTION IN THE ISLAMIC BOARDING SCHOOLS OF HARAMAIN NAHDLATUL WATHAN NARMADA, WEST NUSA TENGGARA
}

\author{
Lalu Ari Irawan \\ Universitas Pendidikan Mandalika \\ Jl. Pemuda No.59A Mataram, 83112 \\ Email: laluariirawan@ikipmataram.ac.id \\ Haerazi \\ Universitas Pendidikan Mandalika \\ Jl. Pemuda No.59A Mataram, 83112 \\ Email: haerazi@ikipmataram.ac.id
}

\begin{tabular}{c|c|c}
\hline Received: & Revised: & Approved: \\
18/06/2019 & $13 / 11 / 2020$ & $14 / 12 / 2020$ \\
\hline
\end{tabular}

DOI: https:/ / doi.org/10.32332/akademika.v25i2.1437

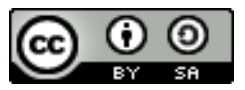

Islamic Cultural Notes in ELT Instruction in the Islamic Boarding Schools of Haramain NW Narmada, West Nusa Tenggara, Licensed Under a Creative Commons Attribution-ShareAlike 4.0 International License

\begin{abstract}
Islamic contents and English were taught at Islamic Boarding School (IBS) Haramain Nahdlatul Wathan (NW) Narmada. English is taught as a general subject and compulsory subject as well. An English community (Language Asrama) is established by Kiai. It is aimed at practicing speaking English and exercising public speaking skills. IBS Haramain NW Narmada includes one of the IBSs in Indonesia in which it reflected Islamic values, cultures, and indoctrination in its teaching and learning. The pieces of evidence showed that this institution taught English for students (Santri) as a tool to gain global information around the world. Dealing with the ELT classrooms, IBS Haramian NW Narmada employed some learning strategies reflecting Islamic cultures and values such as syawir, Lalar, Hafal (memorizing), and Setoran (deposit). The strong emphasis on Arabic and English in daily communication addresses the immersion language program. It is a method applied to teach foreign languages. Based on the application, the IBS Haramain NW Narmada applied a total immersion
\end{abstract}


program, in which Arabic and English are the target languages.

Keywords: Islamic Cultures, ELT Instruction, Cultural Notes, and Islamic Boarding Schools

\section{A. Introduction}

Agus Rois in his book "Teror, Catatan Filsafat dan Politik tentang Firman dan I Islamic boarding schools (IBSs) viewed from the institutional management are an autonomous education. They enable them to create a unique educational system based on their own orientation. Most IBSs in Indonesia have different purposes for getting student-supply. Some IBSs signalize the modern educational systems in their teaching and learning and even in their daily activities around the boarding schools. It is managed so interestingly that other people cannot be intervened unless a Moslem scholar (Kiai) as a founding father. The primary purpose of the IBSs is just more than to internalize the Islamic values and knowledge for their students (called Santri).

According to Zamroni ${ }^{1}$, Islamic boarding schools include an institution to internalize the Islamic values, cultures, and indoctrination for students in order that they are capable of applying those in real social life. Besides, this Islamic institution mirrors indigenous education in Indonesia. In practice, it is also played a role in conducting social empowerment and civil society transformation. Because of this, systems of Islamic boarding schools drive the integrated educational systems and democratic education in sustainable global development.

Islamic boarding schools are well-known as the oldest educational institution in Indonesia. It can be called a unique educational institution because it has specific characteristics compared with a common education institution. They integrate the systems of Islamic education and of modern education in developing students' insight. Students are introduced to the contents of containing yellow books (kitab klasik) and global development. Some Islamic schools, classified as modern Islamic schools, such as Gontor, Sido Giri, Tebu Ireng, and Situbondo in East java, provide students with international languages, Arabic, and English. It is aimed at attaining global information around the world.

The teaching of English as a foreign language in Indonesia declared an important place. Now, English becomes one of the most widely spoken around the world. English as an international language is found in all

1 Zamroni, “Reformulasi Sistem Pendidikan Pesantren Dalam Mengantisipasi Perkembangan Global," Dinamika Ilmu 11, no. 2 (2011): 1-20, https://iain-samarinda.ac.id/ojs/index.php/dinamika_ilmu/article/view/53. 
corners of West Nusa Tenggara, Indonesia. Because English is used to have information and knowledge, it is taught in state and private school educations at some educational levels. According to Patel \& Jail, English is the language of the global village ${ }^{2}$. From these issues, IBSs provide for their students an English camp in the boarding houses. Students have to speak in two languages on different days.

English language teaching model in some IBSs always refers to the social system of English communities. They create an English community to speak both Islamic topics and general issues. It is aimed at practicing speaking English and exercising their pronunciation. According to Richards ${ }^{3}$, ELT instruction must be oriented for getting communicative competencies. Communicative competencies include grammatical competence, sociolinguistic competence, discourse competence, strategic competence, and actional competence ${ }^{4}$. These competencies are so easy to have that students provide full times to practice much more speaking skills. For instance, teachers (ustadz/zah) use English as a language introduction to recite yellow books, although they conduct code-switching (Arab-EnglishIndonesia). It is so helpful that students acquire linguistic knowledge as vocabularies, idioms, pronunciations, and contextual grammars.

Students in Islamic boarding schools feel easy to have communicative competencies either Arabic or English because they stay full day and night in their dormitory. They are guided by teachers. In the learning activities in daily communication, they operate English and Arabic language. They organize time schedules what days they have to speak English or Arabic. They apply a punishment to control students' language activities. Some IBSs educational managements in West Nusa Tenggara adapted the nonclassical educational system and classical educational system. It means that students meet English lessons and even other lessons twice in a day. In the morning, they come to Islamic schools (MTs/MA) called Diniyah and come to schools (SMP/SMA) after that.

The IBSs model integrating Islamic values and modern aspects can be found in West Nusa Tenggara. One of them is the Islamic boarding schools

2 M.F. Patel and Praveen M. Jain, English Language Teaching, English Language Teaching (Methods, Tools, \& Teaching) (Sunrise Publishers \& Distributors, 2017),

https://www.academia.edu/34287801/M_F_Patel_Praveen_M_Jain_English_lang uage_teaching_methods_tools_and_techniques_pdf.

3 Jack C. Richards, Communicative Language Teaching Paradigm, Cambridge University Press, vol. 1, 2006, https://www.professorjackrichards.com/wpcontent/uploads/Richards-Communicative-Language.pdf.

4 Marianne Celce-Murcia, "Rethinking the Role of Communicative Competence," in Intercultural Language Use and Language Learning, 2007, 41-57. 
of Harromain NW, Narmada. This IBS is well-known as a modern Islamic boarding school. It operates two languages (Arab and English) in daily life communication around the boarding house environment. It has a language base-camp (da'arullugoh) for students who intend to develop their two languages. This article was focused on how they study English as a foreign language in the Islamic boarding environment. When they study English, they meet English cultural aspects.

\section{B. English Language Teaching Paradigms}

Teaching English as a foreign language nowadays is not to drive students to be native-like in pronouncing English because English is studied by people who already communicate at least one other language and who live in a community in which English is not normally spoken ${ }^{5}$. English is also taught in all educational institutions nowadays. It is taught as a compulsory subject in private and state educational schools. Its instruction has also been established informally to help language learners to have good ability in English. Therefore, English cannot be denied by everyone, and it is the language of the world that can make the learner a citizen of the world.

In the teaching and learning practice, teachers emphasize language competences in different focuses. The different routes affect various ELT perceptions among teachers. ELT teachers often focus on three instructional paradigms, which are language-centered instruction, learner-centered instruction, and learning-centered instruction ${ }^{6}$. These paradigms bring language teachers and researchers to come to new insight about ELT instruction. For instance, in the ELT classes, students must have knowledge of the cultural target so that students have intercultural competencies 7 . Intercultural language learning emphasizes students to enhance intercultural competences. It can help students internalize their own identity and demonstrate critical awareness of cultural values and beliefs

5 Thomas Ricento, "Considerations of Identity in L2 Learning (Ricento, 2005).Pdf," Handbook of Research in Second Language Teaching and Learning, 2005.

${ }^{6}$ B. Kumaravadivelu, Understanding Postmethod Pedagogy, Beyond Methods: Macrostrategies for Language Teaching, 2003, http:/ / scholar.google.com/scholar?hl=en\&btnG=Search\&q=intitle:Beyond+metho ds\#3\%5Cnhttp:/ / scholar.google.com/scholar?hl=en\&btnG=Search\&q=intitle:Bey ond+methods+macrostrategies+for+language+teaching\#0\%5Cnhttp:/ / ebooks.ca mbridge.org/ref/id/CBO9781107415324A0.

7 Haerazi Haerazi et al., "Incorporating Intercultural Competences in Developing English Materials for Writing Classes," Journal of Language Teaching and Research 9, no. 3 (2018): 540. 
on attitude and behavior8.

The importance of target cultures provided in ELT instruction is echoed by Brown, "whenever teachers teach a language, they teach a complex system of cultural customs, values, and ways of thinking, feeling, and acting9". From here, English teachers are inseparable from teaching cultural features and dimensions in ELT instruction. They often need to design their instructional materials in line with the students' local culture and the target cultures. It is then called by Byram ${ }^{10}$ and Liddicoat ${ }^{11}$ with the intercultural language learning. Intercultural language learning refers to five dimensions proposed by Byram. Those include knowledge, skills, and attitudes ${ }^{12}$. Intercultural-based language learning doesn't mean to study the communities of the target cultures. Students are involved in class to internalize their own culture first before they move to the target cultures. They are asked to discuss and understand the values of their cultures. It is aimed at seeing other cultures based on students' perspectives.

In Indonesia, language and culture are plaited. Indonesia consists of thousands of islands, with hundreds of ethnic groups and hundreds of different cultures. It is very difficult and even impossible to meet a city, a village, or a district that has a single culture. "All cultures have their biases, practices, values, and traditions that are inseparable from the language used in communication"13. Consequently, ELT teachers have to understand a single culture and have to know cultures shared by their students in classes, as well as those shared by the language communities they teach, English. In other words, the ELT teachers in the IBSs should recognize and practice intercultural language learning and multicultural education.

In the same tune with those issues, Margana provides blended

8 Deborah Corder and Alice U-Mackey, "Encountering and Dealing with Difference: Second Life and Intercultural Competence," Intercultural Education 26, no. 5 (2015): 409-424.

${ }^{9}$ H.D. Brown, Methodology in Language Teaching, ed. Jack C Richards and Willy A Renandya (Cambridge: Cambridge University Press, 2002).

${ }^{10}$ Michael Byram, "Intercultural Competence," The Encyclopedia of Applied Linguistics (2012).

11 Anthony J. Liddicoat, "Pedagogical Practice for Integrating the Intercultural in Language Teaching and Learning," Japanese Studies 28, no. 3 (2008): 277-290.

12 Michael Byram, Bella Gribkova, and Hugh Starkey, "Developing the Intercultrual Dimension in Lanugage Teaching A Practical Interoduction for Teachers" (DGIV Council of Europe, 2002), http://www.coe.int/t/dg4/linguistic/source/guide_dimintercult_en.pdf.

${ }^{13}$ Sugirin Sugirin et al., "A Study on Cultural Integration in the English Textbooks for Junior High Schools," Litera 10, no. 2 (2013): 235-246, https://journal.uny.ac.id/index.php/litera/article/view/1167/975. 
cultures in ELT. He further explains that "the blend of the target culture and home culture employed in the ELT process can be conducted in such ways as materials-orientation, learning tasks-orientation, mediaorientation, and assessment-orientation"14. It is aimed at developing students' insight of the home cultures and target cultures. The utilization of blended cultures (home culture, target culture, inter-culture) in ELT classes increases cultural awareness. In addition, Indonesia consisting of hundreds of different cultures, has applied multicultural education. It can help students to acquire "attitudes, knowledge, and skills needed to function within their own micro-culture, mainstream culture, and the global community successfully"15. Added to this, IBSs that teach English formally and informally seems to integrate the Islamic cultures as a home culture and the target cultures, English being taught. ELT teachers have taken into account care to anticipate cultural sensitivities such as having children without marriage, sexy dress, love expression, and religious aspects.

\section{English Language Teaching (ELT) in Islamic Education}

Islamic educations mean educations affiliated with the Islamic religion. Islamic education is one of the national education institutions that have important roles in developing human resources in Indonesia. The Indonesian religious Ministry controls formal Islamic educational institutions. It is different from national institutions that are controlled by the national educational Ministry. Besides, Islamic educations consist of various institutions such as state and private educational levels as MTsN/MAN and MTs/MA. They have the same lessons or subjects shared for students affiliated with the Islamic religion. They study not only Islamic subjects but also general subjects, including English lessons.

English is the most important foreign language learnt by Islamic education students and even by people in the world. The position of English in Indonesia is a foreign language, not as a second language. "English as a foreign language means that it is not used as a spoken language in a country"16, whereas English as a second language refers to a language that is not the main language but used in common communication in a country. In Indonesia, English is taught as a compulsory subject in state or private educational levels. English is taught to obtain communicative competences through integrated learning and

14 Margana, "Proceeding of The 62nd TEFLIN International Conference," in The 62nd TEFLIN International Conference (Denpasar: TEFLIN, 2015), 295-305, http:/ / staffnew.uny.ac.id/upload/132107096/penelitian/blended-cultureenglish-language-teaching.pdf.

${ }^{15}$ M Sinagatullin, Constructing Multicultural Education in a Diverse Society, ScarecrowEducation Book (ScarecrowEducation Book, 2003).

16 Ricento, "Considerations of Identity in L2 Learning (Ricento, 2005).Pdf." 
teaching. In all Islamic educational levels, the four language skills (Listening, Speaking, Reading, and Writing) are learnt simultaneously in ELT classes.

English is not taught in Islamic education from the colonial era to independent era. In the independent era, Islamic education still includes a main field to introduce and spread the Islamic rules by Islamic leaders (imam). The education policy was centered on Moslem scholars (Tuan Guru) to build such Islamic education as MI, MTs, and $\mathrm{MA}^{17}$. The educational patterns and instructional systems are using langgar systems (langgar: a prayer house but not used for Friday prayer) ${ }^{18}$. According to Almas, the educational policy in the Colonial era tends to direct to Moslem scholars in each Islamic education (pesantren) ${ }^{19}$.

Along with the modern era development, Islamic educations go to change physically and systematically. They taught Islamic contents and general subjects such as English. English is taught as a general subject and compulsory subject. Nevertheless, there are some IBSs that have various educational systems. According to Thohir, IBSs can be classified into three types relating to educational systems as follows ${ }^{20}$.

1. Salafi IBSs, it is an Islamic education which provides their students (Santri) with specific Islamic rules. It doesn't teach any except Islamic rules in their educational institutions. The Moslem scholars don't allow students to learn general subjects including English. They learn only yellow books or classical books (Kitab Kuning) and use traditional methods such as memorizing and translation during the instructional learning going on.

2. Khalafi IBSs, Khalafi is called with a modern IBS. It is an IBS implementing classical learning systems such Islamic educational levels as MI/MTs/MA. It is also providing for their students' general subjects and specific skills, including English and Arabic competences. The Khalafi IBS model adapts the state schools and it

17 Sirozi Sirozi, Politik Kebijakan Pendidikan Di Indonesia: Peran Tokoh-Tokoh Islam Dalam Penyusunan UU No.2/1989, Hal.12., n.d.

18 A H Gunawan, Kebijakan Pendidikan Di Indonesia (Jakarta: Bina Aksara, 1986).

19 Afiq Fikri Almas, "Praktik Kebijakan Pendidikan Islam Indonesia Dari Era Pra Kolonial Hingga Kurikulum 2013," Ta'allum: Jurnal Pendidikan Islam 6, no. 1 (2018): 175-196.

${ }^{20}$ Kholis Thohir, "Kurikulum Dan Sistem Pembelajaran Pondok Pesantren Salafi Di Kecamatan Kresek Kabupaten Tangerang Provinsi Banten," Jurnal Analytica Islamica 6, no. 1 (2017): http://garuda.ristekbrin.go.id/journal/view/13268?issue= Vol 6, No 1 (2017): ANALYTICA ISLAMICA. 
is combined with Islamic schools learning and teaching in their Islamic boarding environment.

3. Integrated IBSs, it is an IBS model focused on vocational aspects. Its system is like the job placement training of Ministry of manpower. Their students are provided with specific competences through a centered training. English competence in this IBS is a must to be mastered by their students.

The types of IBSs model in West Nusa Tenggara (NTB) and Indonesia in general are found the three types of the IBSs model mentioned above. The main traits of an IBS consist of a Moslem leader (Tuan Guru/Kiai), a mosque, students (Santri), dormitories, and activities of reciting classical books. ${ }^{21}$ The components of those are tied in the IBS scheme. Besides, IBSs can play many functions. It can be seen from the IBS as educational institutions and informal social empowerment. It plays a role as social development and formal educations to develop Islamic scholars who have future visions. Most of IBSs nowadays can be classified as Khalafi IBSs because they integrate the two functions.

\section{Islamic cultures in ELT Instruction in Islamic Boarding Schools (IBS)}

The way Moslem as an individual practicing Islam is not merely to be seen in how they serve religious duties but is embedded within a particular community's culture from where he/she belongs. It seems to be highly connected to the concept of jama'ah (congregation) among the adherers. As the primary source of Islamic tenets, Koran compels Moslems to place themselves as part of social enterprise, universally as Moslem global group and in smaller social groups. Thus, people begin to transform Islamic laws and tenets into all dimensions of life, including education. Moore ${ }^{22}$ defines Islam as both religion and culture, which is mostly understood by Moslem community as vertical and horizontal practices of becoming Moslem. $\mathrm{Mughal}^{23}$ states Islam as the basis of Moslem culture. Therefore, the way to understand a culture cannot be far from Islamic concepts, which manifested in various affairs.

To accommodate modernity, IBSs also adjust their instructional management by adopting the latest progressive views and innovation in

21 Ibid.

22 Shaiesha Moore, "The Culture of Islam," Berkley Center, last modified 2013, https:/ / berkleycenter.georgetown.edu/posts/the-culture-of-islam.

23 Munir Ahmad Mughal, "International Human Rights and Cultural Relativism," SSRN, no. August (2011): 217, https://papers.ssrn.com/sol3/papers.cfm?abstract_id=1911679. 
the education field. This is what Nizar ${ }^{24}$ mentions as a leap for IBSs to compete with other educational institutions. A report by Pekapontren ${ }^{25}$ concludes that culture of IBSs gives stressing on equality, democracy, and justice, which become catalyst of building society with modern thoughts, but keep maintaining traditionalism and morality. It is also said that IBSs have found plurality and dynamicity as a multicultural institution by engaging of teachers (ustadz), students (santri), society, and government (see also Sudadi) $^{26}$. Ngusman ${ }^{27}$ argues that IBSs are not only functioned as educational institution (formal and non-formal) but also social and missionary ones. This view acknowledges the role of IBSs in society, to acknowledge the roles of kyai - religious preacher who owns an IBS with his family, ustadz, and santri. It is common to see the leader of IBS gives sermon around the boarding house or be invited to some places. The same thing happens to mostly senior ustadz.

\section{E. Teaching Method in Islamic Education System}

Every IBS is practicing varied teaching method, which depends on affiliation of the institution regarding the school of thought embraced. Study by Ngusman $^{28}$ identifies nine methods practiced in an IBS he observed, which is found to have affiliation to salafiyah (traditional) school of thought. Those nine methods are, as follows.

1. Bandungan; in this method, the kyai reads a selected book (reference) about certain topics in front of a group of santri, thus he further explains the meaning and essence of each point in the book. While listening to the kyai, all santri should bring the same book, open the same pages, and make some notes on the selected part of the book. Based on the activity, this method can be recognized as group reading activity combined with the lecture given by the kyai.

2. Sorogan is an individual basis teaching method, in which a santri should see the kyai personally to deliver oral report regarding his

${ }^{24}$ H. S. Nizar and M. Syaifuddin, Contemporary Issues of Islamic Education (Jakarta: Kalam Mulia Publishing, 2010).

25 Tim Pekapontren, Potensi Ekonomi Pondok Pesantren Di Indonesia (Jakarta: Direktorat Pekapontren, 2016).

26 Sudadi Sudadi, Sejarah Pendidikan Islam Di Indonesia (Yogyakarta: Pustaka Ilmu, 2016).

27 Aly Ngusman, "Strategi Pengembangan Pembelajaran Pondok Pesantren Al Falah Somolangu Kebumen," SANGKéP: Jurnal Kajian Sosial Keagamaan 1, no. 2 (2018):

184-197, https://journal.uinmataram.ac.id/index.php/sangkep/article/view/671/376.

${ }^{28}$ Ibid. 
understanding after reading some parts in a certain book. Kyai gives corrective feedback whenever he finds some inaccurate points delivered by the santri. Based on its typology, this method can be viewed as the individual presentation method.

3. Syawir is a method that allows santri to deliver questions or problems based on selected topic as many they can to the kyai. Before giving comments, kyai invites other santri to give their perspectives on the given question or problem.

4. Lalar is modified from bandungan and classroom presentation. Like in bandungan, kyai or ustadz/ustadzah explains the meanings and essences of some parts of a book to a group of santri. After that, santri is given time to learn more in group or individually. Next, santri are selected randomly to present their understanding in front of the class.

5. Mutholangah seems to be bridging activity when a kyai or ustadz recalls santri's memory from previous class sessions. The purpose is to clarify everybody's comprehension on the issues being studied earlier. In some occasions, the teacher asks his/her colleagues to give his/her perspectives regarding the issues on order to enrich learners' understanding. This method is best seen as recalling.

6. Tamrin is better seen as assessment in order to measure learning achievement of the santri. This activity is conducted periodically after completion of one or more chapters of a book. The process is designed as madrasah diniyah (supplement program), not in regular class.

7. Tikror is a method to review topic from the previous session. Santri work in pairs where they have to exchange questions and answer as dyadic activity before starting a new topic.

8. Hafal (memorizing) $\mathcal{E}$ setoran (deposit) is a classical method in IBS. Santri, individually or in group, should memorize a book (mostly written in the forms of verses containing certain theorems about faiths or semantics. After that, they have to present their materials in front of kyai or ustadz.

9. The last method is qiroati, which deals with skill of reciting Koran. A teacher starts with reciting a verse of Koran with perfect style of pronunciation (tajwid and makhroj). Next, santri individually or in group should imitate what they have listened. When they make mistake, kyai or ustadz will give corrective feedback directly.

In this study, those teaching methods, and some others methods from 
different school of thoughts, are identified in FLT class in an attempt to show how Islamic cultures are applied in particular field of interest in IBS. Therefore, this study examines evidences of the use of Islamic cultural features happened to emerge during teaching and learning sessions. The notion of Islamic attributes in the national education system has been proven to occur, especially in schools that have a basis in Islam. A study by Abdurrahman ${ }^{29}$ reports on an Islamic school that adopts an integrated curriculum from three sources, i.e. national curriculum, Gontor curriculum, and salafiyah curriculum. She adds that each of them has particularity differentiating one another in terms of its emphasis. For example, the first system is seen to encourage the use of classical method in teaching and learning process, while Gontor and Salafiyah apply sorogan and bandungan. In the school, this school policy is not limited to in-class activity, but also co-curricular and extra-curricular ones. Abdurrahman also reports the use of Arabic and English as the official languages for daily communication, both at school area and dormitory area. The school is reported to apply holistic education approach by enacting some features, i.e. role-modeling, environment conditioning, guiding, habituation, and task-giving.

\section{F. IBS and Immersion Programs}

The strong view of Islamic cultures also emerges in Foreign Language teaching (FLT), which is marked by how numbers of IBS place English and Arabic as two compulsory foreign languages should be learned by santri (students of IBS). Some of IBSs apply strict policy when dealing with these languages. In this sense, FLT is developed as an immersion program sponsored by school management. In this matter, some IBSs force students to engage only with English or Arabic around school environment. To guarantee this policy, school managements even assign teachers and some selected students to watch and report any violation regarding this policy. In the last decades, this policy has been recognized widely as one of school cultures among IBSs.

In FLT, the strong emphasis on the use of Arabic and English in daily communication addresses the immersion language program, a method applied to teach foreign languages. Many academic reports address Quebec, Canada educational policy as the first immersion program in the world (see Ellis ${ }^{30}$, Walker \& Tedick ${ }^{31}$, and Bostwick ${ }^{32}$ ). Cummins ${ }^{33}$ states the

29 Nana Herdiana Abdurrahman, "Character Education in Islamic Boarding School- Based Sma Amanah," Jurnal Pendidikan Islam 2, no. 2 (2016): 287, https://journal.uinsgd.ac.id/index.php/jpi/article/view/791/683.

30 Rod Ellis, "Principles of Instructed Language Learning," System 33, no. 2 (2005):

209-224, 
first immersion programs are designed to encourage learners to develop proficiency in all target languages by using them in bilingual education. This method has been widely applied in many IBSs in Indonesia. Gontor, an IBS known for placing modernity as its branding, has been leading for its three-language immersion programs, i.e. Indonesian, English, and Arabic. This IBC has inspired many schools all over Indonesia to develop the same program. Based on the application, some IBSs apply total immersion program, in which Arabic and English are the target languages.

\section{G. Attributes of Islamic Cultures in Education Practices}

Besides dealing teaching methods, the Islamic cultures in FLT among IBSs also deals with other practical aspects. The attributes of Islamic cultures can be also traced in various instructional components, such as teaching materials, classroom management, assessments, lesson structures, teaching strategy, and teaching media. In the issue of public speaking, for instance, santri are also trained to be capable public speakers. However, their fluency in delivering speeches in English, they still have to follow the same patterns of speeches commonly used among Moslems, such as in the introduction and closing parts of a speech, as well as in how they address the audience. The evidences are easily found to be used by participants sent by an IBS institution involved in any speech contest. Any jury will find it easy to recognize the patterns of speeches presented by IBS students. The researchers come to this conclusion after having some experiences of being juries in speech contests. Santri from IBSs and Islamic public schools tend to demonstrate unique structure of speech. They always begin their speeches with salam (Islam greeting), gratitude to God, selawat (invocation) for Prophet Muhammad, and reciting certain part(s) of Koran or hadist (Prophet Muhammad's words). By the end of their speeches, they always close it with reciting Koran or hadist and salam (closing greeting). In many cases, they provide translation after giving statements in Arabic. These features of speech have been distinctive style of speech.

https:/ / outspokenela.files.wordpress.com/2017/02/ellis_principles-of-instructedlanguage-learning.pdf.

31 Walker, C. \& Tedick, D. (2000). The complexity of immersion education: Teachers address the issues. Modern Language Journal., 84: 5-24

32 M. Bostwick, "English Language Immersion in a Japanese School," in Bilingual Education, ed. D. Christian and F. Genesse (Alexandria: TESOL, 2001).

33 J. Cummins, Third Language Acquisition Teory and Practice, ed. Michael $\mathrm{H}$ Long and Catherine J Doughty, The Handbook of Language Teaching, vol. 87, 2009, https:/ / scholar.google.com/scholar?hl=en\&as_sdt=0\%2C5\&q=cognitivepsychological+processes+in+second+language+learning\&btnG=\&oq=cognitivepsychological+processes+in+second+language+lea \%0Ahttp:/ / ezproxy.usherbroo ke.ca/login?url=http:/ / search.ebscohost.com/l. 
Talking about the attributes of Islam in education practices may reveal a bulk of unique traditions, such as how the students are expected to behave in interaction with their teachers. In IBS environment, it is common to find students (santri) addressing teachers in dyadic and classroom interaction by saying ustadz (Arabic: male teacher) and ustadzah (Arabic: female teacher), which are also commonly used even in foreign language classes. Whenever they address a particular teacher, they keep addressing them by placing the word ustadz or ustadzah before the teacher's name. Hence, in IBS, the presence of an ustadz/ustadzah in a class is often welcomed by literal salutation from the entire class. Class captain is assigned to give a command to be responded to collectively by other students. Some schools encourage students to give the salutation in Arabic, but also in English in English language classes. This tradition is rooted in Islam, by referring to Islamic tenets about praising teachers.

In a focus group discussion session with some teacher students, the researchers happened to get an interesting perspective of how students engage in an advanced education environment after graduating from IBSs. Mr. Rudy (pseudonym), a senior English teacher in a public senior high school, revealed his interesting outlook regarding his professional judgment towards his students who had experienced IBS before enrolling in Mr. Rudy's public school works. He argued that students from a junior IBS demonstrated very good personal and learning attitudes, which were much better than the students from non-IBS. He also mentioned that those IBS alumna demonstrated better learning endeavors and participation in his class.

During the session, he seems so enthusiastic to seek further explanation regarding this issue, especially to find out what IBSs had given to those students during their junior level education. In this sense, Mr. Rudy concerns about issues of character building in the school system. Some experts might address the answer to Mr. Rudy's inquiry above as holistic education. A school management puts a strong emphasist on how the school (teachers and staff) relates to students as something more essential than the subject content of the lesson. This orientation sets forth exhibitted values by the teachers in all school area as the most prominent issue to be taught to the students. Further discussion on holistic education appears in the next part of this article.

\section{H. Spaces of Holistic Education in IBS}

Some features considered to be addressed to Islamic cultures are further categorized based on the spaces where education processes take place, as follows:

1. Out-class school environment (school policy) 
FLT in IBSs also takes place in school environment among members of school society, i.e. teachers and learners. The researchers happened to witness how ustadz only speak in Arabic or English to santri when they meet each other anywhere in school area. Some schools enact regular (everyday) and nonregular (selected days) policy in using Arabic and English in interaction among teachers and students.

2. In-class school environment (classroom management and teacher's instructions)

Some IBSs regulate the use of Arabic-English only in classroom during classroom sessions or classroom management issues. In classroom environment, some IBSs force ustadz and santri to communicate either in Arabic or English. This may appear in the forms of intra-instructional (teacher's instructions \& learners' talks) and extra-instructional matters (general issues like cleanliness, noise issue, etc.).

3. Dormitory area (IBS management policy)

In many European countries, also in the USA, many private institutions conduct grammar school, which is similar to IBS in how they oblige students to stay in the school accommodation facilities (dormitory). In this kind of school, process of education is continued in accommodation area, which is managed and watched by the school officials. All students are subject of certain rules supervised by the school personnel. In some IBSs, according to some graduates of IBSs, the schools also enact rules about language used in communication, i.e. Arabic and English. Officials have some methods to watch the use of the two languages among santri. According to the same respondents, some people happened to be punished due to violating language policy during bathing time or dinner. This strict language policy has been frightening for some students with low Arabic or English proficiency. They have to be aware of whenever they communicate among themselves considering some santri are assigned as informants.

Those three education spaces mentioned above reflect the practice of holistic education. Students are expected to demonstrate certain behaviors not only in classroom situation, but also in the whole area of IBS. Yamin$\mathrm{Ali}^{34}$ argues that the essential thing from a holistic education is how all

\footnotetext{
34 Jennifer Yamin-Ali, "Holistic Education," n.d., https://uwispace.sta.uwi.edu/dspace/bitstream/handle/2139/6350/Jennifer Yamin-Ali4.pdf?sequence=1.
} 
school elements give contributive engagement towards the gamut of students' growth. In this sense, values being taught by the teachers (both inside and outside a classroom) are the most prominent lessons for students. Therefore, a school with holistic education, including IBS, view education practices as not simply knowledge and skill development in students, but also well-manner (aqidah) in order to build up a strong character of individuals. Furthermore, Yamin-Ali suggests teachers to manage interventions (value-transfer) in all education spaces by considering the framework of action research. Satisfying results of the interventions (considered as small-scale) should be further considered by the school management to enact or expand interventions in a wider scale.

\section{Islamic Cultures in the IBS Haramain NW Narmada}

\section{Islamic Culture and School's Orientation towards English Language Teaching Program}

In operating the school, IBS Haramain NW Narmada's management reflects on their vision and mission statements. The school's vision statement is "good, right, beautiful, useful, and prosperity". The vision is further reflected in a mission statement, "to produce alumnus who loves and fond of good deeds and rightfulness, beuty, useful for people, and live for and to create prosperity for oneself and others". Furthermore, one of the stated indicators towards the vision is improving Arabic and English language skills, both oral and written. Hence, among twelve school's goals, two of them are related to foreign language teaching skills for the teachers and foreign language skills for both teachers and students. The goals are explicitly stated in the school profile.

In IBS Haramain NW Narmada, foreign language mastery is one of the compulsory skills for students. In an attempt to encourage this vision, the school has built and operated a camp area that is also used for an English camp program involving selected students. For this program, the school invites trainers from some prominent institutions, including from university. Participants are selected based on their performances or achievements after conducting assessments towards students. Four students are taken from each boarding room. The goal of recruiting them is to encourage an English learning atmosphere among the students by directing students with strong potential to be peer tutors for their roommates. Appointed students are assigned to make secret notes regarding language violence, which consists of information about what (kinds of violation, e.g. words), who (the violator), when (time of action), and where (location of the action). The student-observers are required to enlist words that seem to be problematic among the students, which also assist the school's language authority in developing 
further solution while the listed vocabulary becomes the input for further course plan.

By enacting strict regulation regarding the use of English and Arabic (randomly scheduled on a fortnight basis) in all areas of the school, the school management applies various types and layers of punishments as the instrument. The use of punishment due to foreign language misconduct is also designated as part of learning in IBS Haramain NW Narmada. Based on the time of giving, the punishment is in two ways, i.e. spontaneous punishment and the regular schedule of reckoning managed by the school language development center in front of all students. There are two types of punishments commonly used. First, the doer is asked to write down (handwriting) five-hundred to a thousand vocabularies. Second, the doer is given five words and its meaning that they should utter loudly while running in the schoolyards. Other students are expected to hear the vocabularies and unconsciously be aware of those vocabularies and its meanings. Therefore, other students can learn from the mistakes made by their mates and to avoid committing the same ones.

\section{Combined English Curricula}

IBS Haramain NW Narmada combines two curricula, i.e. government-based and school-based curriculum systems. The first one is issued by the government, which is known as the Curriculum of 2013 supervised by Department of Religious Affairs. This curriculum leads to the National Examination or Ujian Nasional (henceforth: $\mathrm{UN}$ ) managed by the central government claimed as an instrument for the government to see whether the education sector has been operated completely and evenly across the nation. Some years back, the result of the UN is no longer used as the main consideration of passing grade for students but changed into a minor requirement.

\section{Examination: National vs. School-based}

In IBS Haramain NW Narmada, the school management organizes two examination programs, i.e. national (under the government's policy) and school. The earlier one is similar to what other schools have for final year students as part of their graduation requirements. Meanwhile, the school-based examination is conducted in two types for entire classes, written and oral. This policy also includes English subjects. The senior students get the first chance to complete all exams since they have to take responsibility to be additional examiners for the younger students. 
Each senior student has to be a member of an examiner board that consists of one or two teachers (ustadz) and one senior student. This tradition is rooted in Gontor Islamic Boarding School, in which senior students are given the responsibility to experience an apprentice program at least one year after their graduation.

\section{J. Tracing Islamic Culture in English Language Learning Program}

Viewing Islamic culture in education seems to be challenging due to how the Islam community has been through a long process of blending with the global current colored by multicultural points of view and practices. It requires a comprehensive process of sorting by identifying Islamic cultural markers. To come with a brief understanding of what should be seen as cultural markers, it is essential to adopt a theoretical framework proposed by Irawan $(2017)^{35}$ to recognize the attributes of a particular language. He divides the attributes into two representations, i.e. cultural and linguistic. Coordinator for Language Body in Haramain explains how they also encourage students to learn about English and Arabic cultural features in communication events to enhance their language performances in international interaction though still embracing Islamic values and norms as its platform. Therefore, five of fourteen items suggested by Irawan are obviously rooted from Islamic culture, i.e. perception about physical contact, talking and listening (initiating conversation and attentiveness), acceptable and unacceptable behaviors, religious values, and beliefs. Principally, the school highly suggests that these five cultural items should be practiced based on Islamic tenets.

As mentioned earlier, IBS Haramain NW Narmada combined two curricula, including English subject. The school, however, embraces its education practices by channeling the tradition of Islamic culture. It can be traced not only in the school's mission and vision statements, but also in clasroom practices and the entire education endeavours managed by the school. In terms of classroom practice, it was revealed that six of nine traditional teaching methods were also implemented in English classroom, i.e. syawir, lalar, mutholangah, tamrin, tikror, and hafal. These methods were used to run school-based curricula concerning improvement in speaking and reading skills of the students. However, the procedures were modified to adjust with the English language learning program's needs, which means that not all teaching steps were carried out. Apart from using them, English teachers/tutors did not obviously realize that their methods had rooted in Islamic pedagogical principles. It emerges during interview session. The possible explanation for this is that most of the teachers were graduated from institutions that embraced modern teaching state of the arts or the conventional ones. This view is driven by the fact that none of teacher higher education institution to develop an exclusive foreign language teaching study program on Islamic tradition. Therefore, teachers of IBS tend to have conventional approaches in their teaching. Only an

${ }^{35}$ Lalu Ari Irawan, “(2017). The Atrributes of Indigenous Language and Indonesian Language Affecting EFL Speaking Course of Sasak-Speaking Community. Dissertation, Unpublished. Universitas Negeri Surabaya." (Universitas Negeri Surabaya, 2017). 
IBS with strong Islamic-oriented leadership that may manage tradition of Islamic culture in their foreign language learning programs. The leadership in IBS Haramain NW Narmada, like most other IBSs, are addressed to main figure of the institution, in this case tuan guru (a local term in Sasak to call preacher or kyai as the director of an IBS).

\section{K. Improving English Language Skill through Holistic Education}

Apart from the Yamin-Ali's ${ }^{36}$ claim rejecting an exlusive view on religion as the only source of values to be the basis of holistic education, IBS Haramain NW Narmada exhibits a strong impression of holistic education in the entire school endeavours, both as a system and teachers as individuals. The school's orientation regarding this issue is explicitly stated in a document of school's rofile. Moreover, the school shows its concern about English language teaching by mentioning it in the school's vision and mission statements, which are further implemented in various school programs and policy. A strong orientation on English language teaching has made IBS Haramain NW Narmada to put English into main consideration within the design of holistic education. For instance, the school has a strict policy on acceptable languages used by the students in interaction with teachers and friends. The strong evidence of this in how the school enacts language regulation and rewards and punishments to strengthen this vision. Regarding this, the school, through an internal language body forces students to engage and follow school's policy about foreign language learning that involves teachers and students in all school environment, which includes classrooms, school areas, and boardinghouse area.

The Arabic and English are highly suggested to be used for any kind of interaction, i.e. academic (learning activities) and non-academic (personal and public) purposes. Therefore, English, in this sense, is also used as medium of character building endeavours of the school administrator and teachers. For instance, the use of English (or Arabic) is also compusory in a private chat between students. This denotes how the school forces students to embrace honesty in the students. Once students are caught to break the rule, they should face some kinds of punishments. This language policy also encourages students to be able to have multicultural perspectives of local issues around them by considering how they also learn the foreign languages with the cultural features it may embrace.

\section{Conclusion}

Islamic boarding school of Haramain NW Narmada includes one of the IBSs in Indonesia in which it reflected Islamic values, cultures, and indoctrination in its teaching and learning. The culture of IBSs gives a stressing on equality, democracy, and justice. It becomes catalyst of building society with modern thoughts, but it keeps maintaining traditionalism and morality. For instance, the Harromain IBS found plurality and dynamicity as a multicultural institution by engaging of 
teachers (ustadz), students (santri), society, and government.

It also played a role in conducting social empowerment and civil society transformation. One of the evidence showed that this institution taught English for students (Santri) as a tool to gain global information around the world. Along with the modern era development, as Islamic education, Haramain NW Narmada goes to change physically and systematically. They taught Islamic contents and English. English is taught as a general subject and compulsory subject. English was taught in this institution always refers to social system of English communities. They create an English community (Language Asrama) to discuss both Islamic topics and general issues through English. It is aimed at practicing speaking English and exercising Santri's pronunciation.

The Islamic cultural notes were presented in some ELT classrooms in Haramain NW IBS such; (1) Syawir (Syawir is a method that allows santri to deliver questions or problems based on selected topics as many they can to the kyai. Before giving comments, kyai invites other santri to give their perspectives on the given question or problem); (2) Lalar (Lalar is modified from bandungan and classroom presentation. Like in bandungan, kyai or ustadz/ustadzah explains the meanings and essences of some parts of a book to a group of santri. After that, santri is given time to learn more in group or individually. Next, santri are selected randomly to present their understanding in front of the class); (3) Hafal (memorizing) $\mathcal{E}$ setoran (deposit) is a classical method in IBS. Santri, individually or in a group, should memorize a book (mostly written in the forms of verses containing certain theorems about faiths or semantics. After that, they have to present their materials in front of kyai or ustadz.

\section{REFERENCES}

Abdurrahman, Nana Herdiana. "Character Education in Islamic Boarding School- Based Sma Amanah." Jurnal Pendidikan Islam 2, no. 2 (2016): 287.

https://journal.uinsgd.ac.id/index.php/jpi/article/view/791/683.

Almas, Afiq Fikri. "Praktik Kebijakan Pendidikan Islam Indonesia Dari Era

Pra Kolonial Hingga Kurikulum 2013." Ta'allum: Jurnal Pendidikan Islam 6, no. 1 (2018): 175-196.

Bostwick, M. "English Language Immersion in a Japanese School." In Bilingual Education, edited by D. Christian and F. Genesse. Alexandria: TESOL, 2001.

Brown, H.D. Methodology in Language Teaching. Edited by Jack C Richards and Willy A Renandya. Cambridge: Cambridge University Press, 
2002.

Byram, Michael. "Intercultural Competence." The Encyclopedia of Applied Linguistics (2012).

Byram, Michael, Bella Gribkova, and Hugh Starkey. "Developing the Intercultrual Dimension in Lanugage Teaching A Practical Interoduction for Teachers." DGIV Council of Europe, 2002. http://www.coe.int/t/dg4/linguistic/source/guide_dimintercult_en .pdf.

Celce-Murcia, Marianne. "Rethinking the Role of Communicative Competence." In Intercultural Language Use and Language Learning, 4157, 2007.

Corder, Deborah, and Alice U-Mackey. "Encountering and Dealing with Difference: Second Life and Intercultural Competence." Intercultural Education 26, no. 5 (2015): 409-424.

Cummins, J. Third Language Acquisition Teory and Practice. Edited by Michael H Long and Catherine J Doughty. The Handbook of Language Teaching. Vol. 87, 2009. https://scholar.google.com/scholar?hl=en\&as_sdt=0\%2C5\&q=cogniti ve-

psychological+processes + in + second+language+learning\&btnG=\&oq= cognitive-

psychological+processes+in+second+language+lea \%0Ahttp:// ezprox y.usherbrooke.ca/login?url=http:/ / search.ebscohost.com/l.

Ellis, Rod. "Principles of Instructed Language Learning." System 33, no. 2 (2005):

209-224.

https://outspokenela.files.wordpress.com/2017/02/ellis_principlesof-instructed-language-learning.pdf.

Gunawan, A H. Kebijakan Pendidikan Di Indonesia. Jakarta: Bina Aksara, 1986.

Haerazi, Haerazi, Dedi Irwansyah, Juanda Juanda, and Yek Amin Azis. "Incorporating Intercultural Competences in Developing English Materials for Writing Classes." Journal of Language Teaching and Research 9, no. 3 (2018): 540.

Irawan, Lalu Ari. "(2017). The Atrributes of Indigenous Language and Indonesian Language Affecting EFL Speaking Course of SasakSpeaking Community. Dissertation, Unpublished. Universitas Negeri Surabaya." Universitas Negeri Surabaya, 2017.

Kumaravadivelu, B. Understanding Postmethod Pedagogy. Beyond Methods: Macrostrategies for Language Teaching, 2003. http://scholar.google.com/scholar?hl=en\&btnG=Search\&q=intitle:Be yond+methods\#3\%5Cnhttp:// scholar.google.com/scholar?hl=en\&btn $\mathrm{G}=$ Search\&q=intitle:Beyond+methods+macrostrategies+for+language 
+teaching\#0\%5Cnhttp://ebooks.cambridge.org/ref/id/CBO97811074 15324A0.

Liddicoat, Anthony J. "Pedagogical Practice for Integrating the Intercultural in Language Teaching and Learning." Japanese Studies 28, no. 3 (2008): 277-290.

Margana. "Proceeding of The 62nd TEFLIN International Conference." In The 62nd TEFLIN International Conference, 295-305. Denpasar: TEFLIN, 2015.

http:// staffnew.uny.ac.id/upload/132107096/penelitian/blendedculture-english-language-teaching.pdf.

Moore, Shaiesha. "The Culture of Islam." Berkley Center. Last modified 2013. https://berkleycenter.georgetown.edu/posts/the-culture-ofislam.

Mughal, Munir Ahmad. "International Human Rights and Cultural Relativism." SSRN, no. August (2011): 217. https:/ / papers.ssrn.com/sol3/papers.cfm?abstract_id=1911679.

Ngusman, Aly. "Strategi Pengembangan Pembelajaran Pondok Pesantren

Al Falah Somolangu Kebumen." SANGKéP: Jurnal Kajian Sosial $\begin{array}{llllll}\text { Keagamaan } & 1, & \text { no. } & 2 & \text { (2018): }\end{array}$ https://journal.uinmataram.ac.id/index.php/sangkep/article/view/ $671 / 376$.

Nizar, H. S., and M. Syaifuddin. Contemporary Issues of Islamic Education. Jakarta: Kalam Mulia Publishing, 2010.

Patel, M.F., and Praveen M. Jain. English Language Teaching. English Language Teaching (Methods, Tools, \& Teaching). Sunrise Publishers \& Distributors, 2017. https://www.academia.edu/34287801/M_F_Patel_Praveen_M_Jain_ English_language_teaching_methods_tools_and_techniques_pdf.

Ricento, Thomas. "Considerations of Identity in L2 Learning (Ricento, 2005).Pdf." Handbook of Research in Second Language Teaching and Learning, 2005.

Richards, Jack C. Communicative Language Teaching Paradigm. Cambridge University Press. Vol. 2006. https://www.professorjackrichards.com/wpcontent/uploads/Richards-Communicative-Language.pdf.

Sinagatullin, M. Constructing Multicultural Education in a Diverse Society. ScarecrowEducation Book. ScarecrowEducation Book, 2003.

Sirozi, Sirozi. Politik Kebijakan Pendidikan Di Indonesia: Peran Tokoh-Tokoh Islam Dalam Penyusunan UU No.2/1989, Hal.12., n.d.

Sudadi, Sudadi. Sejarah Pendidikan Islam Di Indonesia. Yogyakarta: Pustaka Ilmu, 2016.

Sugirin, Sugirin, Siti Sudatini, Suciati Suciati, and Lusi Nurhayati. "A Study 
406 AKADEMIKA: Jurnal Pemikiran Islam

, Vol. 25, No. 02 Juli - Desember 2020

on Cultural Integration in the English Textbooks for Junior High Schools." Litera 10, no. 2 (2013): 235-246. https://journal.uny.ac.id/index.php/litera/article/view/1167/975.

Thohir, Kholis. "Kurikulum Dan Sistem Pembelajaran Pondok Pesantren Salafi Di Kecamatan Kresek Kabupaten Tangerang Provinsi Banten." Jurnal Analytica Islamica 6, no. 1 (2017): 11-21. http://garuda.ristekbrin.go.id/journal/view/13268?issue= Vol 6, No 1 (2017): ANALYTICA ISLAMICA.

Tim Pekapontren. Potensi Ekonomi Pondok Pesantren Di Indonesia. Jakarta: Direktorat Pekapontren, 2016.

Yamin-Ali, Jennifer. "Holistic Education," n.d. https://uwispace.sta.uwi.edu/dspace/bitstream/handle/2139/6350/ Jennifer Yamin-Ali4.pdf?sequence=1.

Zamroni. "Reformulasi Sistem Pendidikan Pesantren Dalam Mengantisipasi Perkembangan Global." Dinamika Ilmu 11, no. 2 (2011): $1-20$. https://iainsamarinda.ac.id/ojs/index.php/dinamika_ilmu/article/view/53. 